УДК: 615.454.1: $615.28: 615.076$

DOI: $10.15587 / 2519-4852.2017 .108947$

\title{
DETERMINATION OF THE STABILITY OF VETERINARY CREAM CONTAINING SILVER CITRATE
}

\section{(C) Z. Polova}

Інновачійна діяльність в галузі створення українських лікарських препаратів для ветеринарної фармаџії є актуальним питанням. Так, проблема лікування та профілактики маститу у корів є не вирішеною. Майже всі наявні на ринку протимаститні препарати являють собою антибіотики, щяо посилює існуючу проблему з виникнення антибіотикорезистентності у мікроорганізмів, вирішення якої можливо за рахунок розробки нових ветеринарних препаратів з мінімальними побічними ефектами та максимальною терапевтичною ефективністю.

Мета. Дослідження стабільності ветеринарного препарату з ичитратом срібла у складі м'якої лікарської форми антимікробної дї під умовною назвою «Аргоичид К».

Методи. Фармако-технологічні, фізико-хімічні, та мікробіологічні методи досліджень проводили згідно з вимогами Державної Фармакопеї Украӥни.

Результати дослідження. Вивчення стабільності зразків крему «Аргоцид К» проводили на п'яти серіях препарату, розфасованого в туби алюмінієві з внутрішнім лаковим покриттям та банки із жовтогарячого скла на протязі 27 місячів кожні 6 місяців. Термін зберігання крему визначали при двох температурних режимах - при кімнатних умовах $15-25^{\circ} \mathrm{C}$ і в прохолодному місиі при $8-15^{\circ} \mathrm{C}$. В результаті експерименту встановлено, щзо усі серії зразків ветеринарного крему «Аргочид К» витримують випробування на термо- та колоїдну стабільність. Кількісний вміст іонів срібла визначали тіоціанометрично. Кількісне визначення декспантенолу проводили методом рідинної хроматографії. Одержані дані свідчили про стабільність препарату.

Мікробіологічними дослідженнями встановлено, щуо за ступенем мікробної контамінації препарат відповідає вимогам Державної Фармакопеї Украӥни для препаратів місчевого застосування. Цитрат срібла, який входить до складу крему, у досліджуваній концентрації володіє консервуючою дією.

Висновки. Встановлено термін придатності крему - 2 роки та 3 місяиі. Результати дають можливість прогнозувати термін зберігання препарату протягом двох років та трьох місяців при температурі 8-25 ${ }^{\circ} \mathrm{C}$ та можуть бути враховані при розробиі проекту методик контролю якості на крем «Аргочид К》 для застосування у ветеринарії

Ключові слова: ветеринарний препарат, крем для догляду за дійками вимені корів, цичтрат срібла, стабільність

\section{Introduction}

Compliance with GMP requirements by Ukrainian manufacturers of medicinal products (MP) ensures the stable production of remedies in accordance with the requirements of the normative and technical documentation and quality control according to the analytical normative documentation (AND). The EU Directive 89/341 / EEC, it is noted that "the quality of medicinal products should be maintained by requiring compliance with the principles of good manufacturing practice". Substandard medicines are dangerous for people's health, and also they lead to material damage both for the state and for the consumer. In Ukraine, implementation of the good practices requirements for veterinary drugs (VD) production is being implemented.

The EU Council has adopted directives concerning the principles and rules of GMP for MP and VD. Directive 2003/94/EC refers to remedies for human use, and Directive 91/412/EEC - to drugs for veterinary use. The detailed requirements that meet the Directive 91/412/EEC principles [1] are displayed in the "Methodological Recommendations on the Basic Rules for Good Manufacturing Practice and Quality Control of Veterinary Medicines", on the basis of which Ukrainian VD manufacturers will be inspected [2].

To ensure the production of high-quality VD, it is necessary to implement and comply with the standards and Good Manufacturing Practice requirements, which are unified for all manufacturers, tested by time and experience, and ensure the production of remedies with specified characteristics that meet the requirements of regulatory documents (the European Pharmacopoeia and the State Pharmacopoeia). Drug stability and shelf-life the time period without adverse changes in physical, chemical, pharmacological and consumer characteristics observed - is an important indicator of its quality.

2. Formulation of the problem in a general way, the relevance of the theme and its connection with important scientific and practical issues

An innovative activity in the field of development of new Ukrainian medicines for veterinary pharmacy remains relevant. In the Ukrainian market there is a need to develop new safe drugs for prevention and treatment of obstetric and gynecological disorders of cattle. Thus, the problem of treatment and prevention of mastitis in cows has not been solved, and in this connection the damage due to the disease causes a significant damage to the dairy industry. Growing cases of cows' mastitis in dairy farms lead to a decrease in milk productivity, premature ejection of the animals, and deterioration of technological properties of milk. Also, the duration of mastitis treatment is significantly affects on the cattle productivity. Every day of treatment metabolic products of bacteria accumulate in the affected parts of udder that 
cause death and desquamation of the mammary gland epithelium. Almost all available anti-mastitis drugs on the market are either antibiotics or combination drugs containing antibiotics, which exacerbates the existing problem of antibiotic resistance in microorganisms, the solution of which is possible by developing new VD with minimal side effects and maximum therapeutic efficacy.

\section{Analysis of recent studies and publications in which a solution of the problem and which draws on the author}

Among the main cattle diseases, mastitis occupies a special place, due to its widespread distribution and great economic damage to milk manufacturers, processing industry and human health [3].

The most widespread mastitis in cows occurs during start, dry cow period and at the beginning of lactation $[4,5]$. Etiological factors of the given disease may be violations of technology and rules of milking, conditions of retention and feeding ща cows [6]. However, various microorganisms are one of the main causes of mastitis development $[7,8]$.

To ensure cow's mammary gland health and the normative indicators of milk quality, among which bacterial contamination is the most important, special attention should be paid to udder hygiene, which is in its care by special means before and after milking $[9,10]$.

The most popular solutions are antiseptics and disinfectants are sodium hypochloride, iodophor solution, chlorhexidine, dodecylbenzenesulfonic acid, peracetic acid. The use of the aforementioned sanitary-hygienic means allows reducing the microbial contamination of the udder skin $[11,12]$.

Without such prevention, inflammatory processes caused by penetration of pathogenic microorganisms into the animal's body through the skin may develop in the mammary gland [13]. As a result of mastitis development, the number of leukocytes in milk increases and biochemical parameters of blood change [14].

However, prolonged use of chemical disinfectants can cause udder skin irritation and even dermatitis [15]. Priority of the proposed remedies is a complex of synthetic compounds containing antibiotics, which cause mastitis pathogens resistance $[16,17]$. Therefore, recently veterinary medicine specialists began to use herbal medicinal products for the treatment of various diseases in animals, including mastitis, which minimize the negative impact on the immune status of animals and are environmentally safe in comparison with traditional drugs [18].

Ukrainian researchers developed the remedy for the treatment and prevention of udder dermatitis and mastitis in cows "Phytoserus", which includes Tea tree, Cajuput, Pine, Common juniper, Clove and Eucalyptus essential oils [19].

The subclinical mastitis can be prevented by cattle udder care. Russian scientists developed remedy "Stop mastitis", which forms a stable protective film on the udder, preventing microorganisms' penetration into the mammary ducts. The protective layer is kept on the skin for up to 4-5 hours. "Stop mastitis" softens and increases the elasticity of the udder skin, and has antimicrobial and wound healing effect [20].
There is information about the effective use of nano aqua-chelates in treatment of subclinical forms of mastitis. Metals nano aqua-chelates with biogenic and biocidal properties is a wide class of functional nanomaterials from colloidal solutions of metals hydrated nanoparticles to metal nanocarboxylates [21].

Compounds of such metal as silver cause practical interest.

Remedies containing silver compounds are widely used in humane medicine: to accelerate healing, to treat stomach ulcers, silver threads are used as suture material, silver coated catheters for urine removal. At the end of the 19th century, a solution of silver nitrate and colloidal silver drugs Collargol and Protargol, were offered for ophthalmic infections of newborns as effective antimicrobial agents. However, these drugs had a number of disadvantages, and the need for multiple applications, uncontrolled release of silver ions and their inactivation by biological tissues were the main of them [22].

The new promising pharmaceutical ingredient, silver citrate, was studied in the soft dosage form codenamed "Argocid K". Research of the antimicrobial activity of the samples proved that the therapeutic and prophylactic cream "Argocid K" for udder care has bacteriostatic and bactericidal activity against multiresistant clinical strains of different types of microorganisms [23].

\section{Allocation of unsolved parts of the general problem, which is dedicated to the article \\ Stability is an important indicator of VD quality; it is the time period with no adverse changes in physico- chemical, pharmacological and consumer characteristics of the drug. For multidose drugs, which are creams, pharmaceutical testing should allow determination of the storage period for VD during their use and their shelf life after the first opening of the container. When developing the composition of an innovative veterinary drug, the expiration date is determined experimentally by periodic evaluation of all quality indicators specified in the AND.}

\section{Formulation of goals (tasks) of Article}

The aim of the study was to determine the stability of the veterinary drug in accordance with the State Pharmacopoeia of Ukraine requirements [24]. Soft veterinary drugs for external use are monitored by such quality indicators as description, identification, homogeneity, mass of the container content, microbiological purity, and quantitative determination. If necessary, additional control of the particle size, $\mathrm{pH}$, acid number, the base specific properties, impurities content, and tightness of the container are being determined.

6. Statement of the basic material of the study (methods and objects) with the justification of the results

"Argocid K" samples were used for research. Stability tests were carried out on five series of the remedy, packed in aluminum tubes (Technical Conditions of Ukraine 25463020-01-98) with an interior coating of Rasias 11015-000, as well as orange glass jars BDS-2027,5- OS-1 (TC 64-2-239-79) with tight-fitting covers type 1 (OST 64-2-87-81) for 27 months every 6 months. The shelf life of the cream was determined at two tem- 
perature modes - at room temperature $15-25^{\circ} \mathrm{C}$ and in a cool place at $8-15^{\circ} \mathrm{C}$. The results of the research are shown in Table $1,2$.

The study was carried out on the basis of the departments of the National University of Pharmacy (NUPh) under the cooperation agreement between NUPh (Industrial Pharmacy and Industrial Technology of Drugs Departments and O. O. Bohomolets National Medical University (Pharmacy and Industrial Technology of Drugs Department).

The determination and control of the appearance and organoleptic properties of the cream samples (color, odor, consistency, etc.) were performed by visual and organoleptic methods according to the SPhU (1st Ed., 2.2.3). The cream should be homogeneous (no visible particles, extraneous inclusions, signs of physical instability: aggregation, coalescence, particles coagulation).

Experimental stability studies of the emulsion cream most objectively characterize their resistance to temperature and centrifuge fluctuations (colloidal and thermal stability). To determine the colloidal stability of the VD, laboratory centrifuge with a set of test-tubes, a mercury thermometer with temperature measurement interval from 0 to $100{ }^{\circ} \mathrm{C}$ and value of division of a $1{ }^{\circ} \mathrm{C}$, as well as a stopwatch and water bath, were used. Test tube was filled to $2 / 3$ of its volume by the samples of the veterinary cream. Then, the test tubes were placed into a water bath at a temperature of $45 \pm 2{ }^{\circ} \mathrm{C}$ for 20 minutes. Then, they were centrifuged for 5 minutes. The sample was considered to be stable in case of the absence of stratification after centrifugation.

Thermal stability determination of was carried out according to the methodology given in the National Standard of Ukraine "Cosmetic creams. General specifications: SSU 4765: 2007. - [Valid from 01/01/2009]». A test tube containing $10 \mathrm{~g}$ of the cream was placed into a thermostat TV-80-1 with a temperature of $40-42{ }^{\circ} \mathrm{C}$ and it was left for one week; then it was transferred to a refrigerator at a temperature of $10-12{ }^{\circ} \mathrm{C}$ for the same period, after which it was kept for 3 days at a room temperature.

In result of the experiment it was identified that all series of samples of the veterinary cream "Argocid K" withstanded trials for thermal and colloidal stability.

Quality preservation of remedies for use in veterinary medicine is an important indicator, since reducing the quantitative content of active pharmaceutical ingredients in the drug points to its instability. The quantitative determination of silver ions in the VD was carried out using thiocyanometric titration method. Dexpanthenol quantitative content was determined by liquid chromatography (SPhU 2.2.29). The obtained data testified to the stability of the veterinary cream "Argocid K".

Table 1

Results of stability testing of "Argocid K" cream during storage period in orange glass jars within 2 years and 3 months

\begin{tabular}{|c|c|c|c|c|c|c|}
\hline \multirow{2}{*}{ Sample name acccording to the QCM } & \multirow{2}{*}{$\begin{array}{l}\text { Start of the } \\
\text { experiment }\end{array}$} & \multicolumn{5}{|c|}{ Storage period, months. } \\
\hline & & 6 & 12 & 18 & 24 & 27 \\
\hline \multicolumn{7}{|c|}{ at a temperature $(8 \pm 15)^{\circ} \mathrm{C}$} \\
\hline Appearance & \multicolumn{6}{|c|}{ White cream with a slight smell of citric acid } \\
\hline Homohenity & \multicolumn{6}{|c|}{ Homogeneous content } \\
\hline Colloidal stability & \multicolumn{6}{|c|}{ Stable } \\
\hline Thermal stability & \multicolumn{6}{|c|}{ Stable } \\
\hline $\begin{array}{l}\text { Identification: Silver ions (from } 0.510 \\
\text { to } 0.525 \mathrm{mg} / \mathrm{g} \text { ) }\end{array}$ & $0,524 \pm 0,001$ & $0,523 \pm 0,001 \mid$ & $0,524 \pm 0,001$ & $0,523 \pm 0,001$ & $0,523 \pm 0,001$ & $0,522 \pm 0,002$ \\
\hline $\begin{array}{c}\text { Dexpanthenol quantitative content in } \\
100.0 \mathrm{~g} \text { of the cream (from } 5.100 \text { to } \\
5.250 \mathrm{~g} \text { ) }\end{array}$ & $5,105 \pm 0,04$ & $5,105 \pm 0,03$ & $5,104 \pm 0,05$ & $5,103 \pm 0,01$ & $5,104 \pm 0,01$ & $5,101 \pm 0,04$ \\
\hline $\begin{array}{l}\text { Total viable aerobic microorganisms: less } \\
\text { than } 102 \mathrm{CFU} / \mathrm{g} \text {, total amount of yeast } \\
\text { and mold fungi less than } 101 \mathrm{CFU} / \mathrm{g}, \mathrm{S} \text {. } \\
\text { aureus, } \mathrm{P} \text {. aeruginosa and Enterobacteri- } \\
\text { aceae bacteria are not allowed in } 1 \mathrm{~g}\end{array}$ & \multicolumn{6}{|c|}{ Corresponds } \\
\hline \multicolumn{7}{|c|}{ at a temperature $(15 \pm 25)^{\circ} \mathrm{C}$} \\
\hline Appearance & \multicolumn{6}{|c|}{ White cream with a slight smell of citric acid } \\
\hline Homohenity & \multicolumn{6}{|c|}{ Homogeneous content } \\
\hline Colloidal stability & \multicolumn{6}{|c|}{ Stable } \\
\hline Thermal stability & \multicolumn{6}{|c|}{ Stable } \\
\hline $\begin{array}{c}\text { Identification: Silver ions (from } 0.510 \\
\text { to } 0.525 \mathrm{mg} / \mathrm{g} \text { ) }\end{array}$ & $0,524 \pm 0,001$ & $0,523 \pm 0,002$ & $0,524 \pm 0,001$ & $0,523 \pm 0,001$ & $0,523 \pm 0,001$ & $0,522 \pm 0,002$ \\
\hline $\begin{array}{c}\text { Dexpanthenol quantitative content in } \\
100.0 \mathrm{~g} \text { of the cream (from } 5.100 \text { to } \\
5.250 \mathrm{~g} \text { ) }\end{array}$ & $5,104 \pm 0,02$ & $5,105 \pm 0,03$ & $5,102 \pm 0,01$ & $5,101 \pm 0,02$ & $5,102 \pm 0,03$ & $5,101 \pm 0,04$ \\
\hline $\begin{array}{c}\text { Total viable aerobic microorganisms: } \\
\text { less than } 102 \mathrm{CFU} / \mathrm{g} \text {, total amount of } \\
\text { yeast and mold fungi less than } 101 \\
\mathrm{CFU} / \mathrm{g}, \mathrm{S} \text {. aureus, P. aeruginosa and } \\
\text { Enterobacteriaceae bacteria are not } \\
\text { allowed in } 1 \mathrm{~g}\end{array}$ & \multicolumn{6}{|c|}{ Corresponds } \\
\hline
\end{tabular}

Note: $\mathrm{P} \pm 95 \%, \mathrm{n}=5$ 
It should be noted that there are special requirements to VD for cows' udder care, as follows: protection the mammary ducts from pathogenic microorganisms and favorable effect on the udder skin. Also, $\mathrm{pH}$ of the drug has a particular importance. The Swedish company DeLaval, which since 1883 has been working on the problem of cows' productive longevity, at development of remedies for cattle's udder care, pays close attention to all factors that can affect the udder health [25]. Determination of the $\mathrm{pH}$ of the"Arghocid $\mathrm{K}$ " cream made it possible to determine that, depending on the series, this index is 6.3-7.0, which is consistent with the physiological data on the $\mathrm{pH}$ of the skin of the animal's udder.

Determination of $\mathrm{pH}$ was carried out according to the $\mathrm{SPhU} 1^{\mathrm{st}}$ Edition. Determination of $\mathrm{pH}$ of water extracts. $5.0 \mathrm{~g}$ of the cream (exact weight) was placed into a $100 \mathrm{ml}$ chemical glass and dissolved in $50 \mathrm{ml}$ of purified water using glass stirring rod, then it was left for $10 \mathrm{mi}-$ nutes for insoluble components sedimentation, and after that the $\mathrm{pH}$ of the obtained aqueous dispersion was determined potentiometrically ( $\mathrm{SPhU} 1^{\text {st }}$ Edition, Supplement 1 (2004), p. 2.2.3, p. 17).

Table 2

Results of stability testing of "Argocid K" cream during storage period in Aluminium tubes within 2 years and 3 months

\begin{tabular}{|c|c|c|c|c|c|c|}
\hline \multirow{2}{*}{$\begin{array}{c}\text { Sample name acccording } \\
\text { to the QCM }\end{array}$} & \multirow{2}{*}{$\begin{array}{l}\text { Start of the } \\
\text { experiment }\end{array}$} & \multicolumn{5}{|c|}{ Storage period, months. } \\
\hline & & 6 & 12 & 24 & & 7 \\
\hline \multicolumn{7}{|c|}{ at a temperature $(8 \pm 15){ }^{\circ} \mathrm{C}$} \\
\hline Appearance & \multicolumn{6}{|c|}{ White cream with a slight smell of citric acid } \\
\hline Homohenity & \multicolumn{6}{|c|}{ Homogeneous content } \\
\hline Colloidal stability & \multicolumn{6}{|c|}{ Stable } \\
\hline Thermal stability & \multicolumn{6}{|c|}{ Stable } \\
\hline $\begin{array}{c}\text { Identification: Silver } \\
\text { ions (from } 0.510 \text { to } \\
0.525 \mathrm{mg} / \mathrm{g} \text { ) }\end{array}$ & $0.524 \pm 0.001$ & $0.523 \pm 0.001$ & $0.524 \pm 0.001$ & $0.523 \pm 0.001$ & $0.523 \pm 0.001$ & $0.522 \pm 0.002$ \\
\hline $\begin{array}{l}\text { Dexpanthenol quantita- } \\
\text { tive content in } 100.0 \mathrm{~g} \text { of } \\
\text { the cream (from } 5.100 \text { to } \\
5.250 \mathrm{~g})\end{array}$ & $5.105 \pm 0.04$ & $5.105 \pm 0.03$ & $5.104 \pm 0.05$ & $5.103 \pm 0.01$ & $5.104 \pm 0.01$ & $5.101 \pm 0.04$ \\
\hline $\begin{array}{c}\text { Total viable aerobic } \\
\text { microorganisms: less } \\
\text { than } 102 \mathrm{CFU} / \mathrm{g} \text {, total } \\
\text { amount of yeast and } \\
\text { mold fungi less than } 101 \\
\mathrm{CFU} / \mathrm{g}, \mathrm{S} \text {. aureus, P. } \\
\text { aeruginosa and Entero- } \\
\text { bacteriaceae bacteria are } \\
\text { not allowed in } 1 \mathrm{~g}\end{array}$ & \multicolumn{6}{|c|}{ Corresponds } \\
\hline \multicolumn{7}{|c|}{ at a temperature $(15 \pm 25)^{\circ} \mathrm{C}$} \\
\hline Appearance & \multicolumn{6}{|c|}{ White cream with a slight smell of citric acid } \\
\hline Homohenity & \multicolumn{6}{|c|}{ Homogeneous content } \\
\hline Colloidal stability & \multicolumn{6}{|c|}{ Stable } \\
\hline Thermal stability & \multicolumn{6}{|c|}{ Stable } \\
\hline $\begin{array}{c}\text { Identification: Silver } \\
\text { ions (from } 0.510 \text { to } \\
0.525 \mathrm{mg} / \mathrm{g} \text { ) }\end{array}$ & $0.524 \pm 0.001$ & $0.523 \pm 0.002$ & $0.524 \pm 0.001$ & $0.523 \pm 0.001$ & $0.523 \pm 0.001$ & $0.522 \pm 0.002$ \\
\hline $\begin{array}{l}\text { Dexpanthenol quantita- } \\
\text { tive content in } 100.0 \mathrm{~g} \text { of } \\
\text { the cream (from } 5.100 \\
\text { to } 5.250 \mathrm{~g} \text { ) }\end{array}$ & $5.104 \pm 0.02$ & $5.105 \pm 0.03$ & $5.102 \pm 0.01$ & $5.101 \pm 0.02$ & $5.102 \pm 0.03$ & $5.101 \pm 0.04$ \\
\hline $\begin{array}{c}\text { Total viable aerobic } \\
\text { microorganisms: less } \\
\text { than } 102 \mathrm{CFU} / \mathrm{g} \text {, total } \\
\text { amount of yeast and } \\
\text { mold fungi less than } 101 \\
\mathrm{CFU} / \mathrm{g}, \mathrm{S} \text {. aureus, } \mathrm{P} . \\
\text { aeruginosa and Entero- } \\
\text { bacteriaceae bacteria are } \\
\text { not allowed in } 1 \mathrm{~g}\end{array}$ & \multicolumn{6}{|c|}{ Corresponds } \\
\hline
\end{tabular}

Note: $\mathrm{P} \pm 95 \%, \mathrm{n}=5$

The container tightness was also determined by the method of the SPhU $1^{\text {st }}$ Edition, p. 511, by keeping the required number of tubes with cream (10) in a thermostat at a temperature of $60 \pm 3{ }^{\circ} \mathrm{C}$ for 8 hours. The 
given test is due to the fact that the container's poor tightness can lead to loss of the drug, its microbial contamination, and also to the decrease of stability under the influence of environmental factors on contents of the container. The mass of the package content was determined in accordance with the method of the SPhU 1.1, p. 86. All tested samples of the veterinary cream "Argocid $\mathrm{K}$ " met the requirements of the AND on the remedy.

The problem of soft dosage forms contamination is extremely important. Even the presence in the VD of substances having antimicrobial activity (silver citrate in our case), can affect microorganisms. However, substances with antimicrobial activity do not always guarantee the microbiological purity of drugs, which may be due to the lack of self-sterilizing effect concerning microorganisms out of its specific action spectrum. Also, auxiliary substances as a part of VD may cause contamination. Herbal material is often the reason of microbial contamination; synthetic substances are less contaminated with microorganisms, although there are very contaminated ones among them.

That is why the next stage of the experiment was microbiological purity tests of veterinary cream "Argocid K" samples. The study was carried out at the D. K. Zabolotny Institute of Microbiology and Virology, NAS of Ukraine (Consultant - Head of Department of Interferon and Immunomodulators, NAS of Ukraine member, M. Ya. Spivak) according to The SPhU 1st Edition, 2.6.12 and 2.6.13 (microbiological purity tests). The tests were performed using the direct sowing method. The sample mass was $10.0 \mathrm{~g}$, dilution - 1:10. Assessment of microbial contamination of test samples consisted of determination of total aerobic bacteria and fungi in the 1.0 of the sample, as well as the absence of Enterobacteriaceae, Staphylococcus aureus and Pseudomonas aeruginosa bacteria.

The results of microbiological studies have shown that Enterobacteriaceae, Staphylococcus aureus and Pseudomonas aeruginosa bacteria were not detected in the "Arghocid K" samples during the observation period. According to the microbial contamination degree, the drug meets the SPhU $1^{\text {st }}$ Edition requirements for topical preparations.

For non-sterile VD, in addition to manufacturing conditions, the main factor that provides microbiological purity during production and storage period is antimicrobial preservatives efficiency. In accordance to the current requirements at the registration stage of the drug, it is necessary to provide experimental data confirming the antimicrobial preservatives efficiency. Silver citrate, as a component of "Argocid K" veterinary cream, is widely used in Europe and the United States in the production of cosmetic products [26]. Antimicrobial preservatives efficiency tests were carried out in accordance with the $\mathrm{SPhU} 1^{\text {st }}$ Edition, 5.1.3. requirements. For this purpose, standard nutrient media and the following test microorganisms were used: Pseudomonas aeruginosa ATCC 9027, Staphylococcus aureus ATCC 6538, Candida albicans ATCC 10231, and Aspergillus niger ATCC 16404.

The estimation criterion concerning preservatives efficiency in the dosage form is reduction of the amount of viable cells of test-microorganisms in the drug for a certain period of time after its contamination. In accordance with the $\mathrm{SPhU}$ requirements, the logarithm of reducing the viable cells of bacteria amount in 14 days should be more than three, and the number of viable cells of bacteria should not increase in future; the logarithm of reducing the viable fungi cells amount in 14 days should be at least one, and the amount of viable fungi cells should not increase in future.

According to preliminary studies, silver citrate, as a component of the cream, inhibits the growth of microorganisms in the studied concentration [23]. There is no need in additional antimicrobial preservatives for "Argocid K" cream for cows' udder.

\section{Findings from the research and prospects of further development of this area}

1. Modern pharmaco-technological, physico-chemical, and microbiological methods were used for the study that made it possible to estimate objectively samples of a veterinary drug codenamed "Argocid K".

2 . In result of the study it was determined that organoleptic and physico-chemical properties (thermal and colloidal stability) of the cream meet requirements of the SPhU indexes both immediately after production, and after all the shelf life in the aluminum tubes and orange glass jars.

3. Quantitative determination of the active pharmaceutical ingredients - silver citrate and dexpanthenol in the cream composition was carried out. The obtained data point to the drug stability within the whole storage period.

4. Microbiological studies have shown that the drug according to its microbial contamination level meets the $\mathrm{SPhU}$ requirements for topical drugs.

5 . The storage period was determined -2 years and 3 months. The obtained results make it possible to predict the drug storage period within 2 years and 3 months at a temperature $8-25^{\circ} \mathrm{C}$ and can be considered at Draft quality control methods development for "Argocid K" veterinary cream.

\section{References}

1. Commission Directive 91/412 EEC 23.07.1991 [Text]. - Official Journal of the European Communities. - 1991. - Vol. L 228/70. - P. 17.8.91.

2. Metodychni rekomendatsii shchodo osnovnykh pravyl nalezhnoi praktyky vyrobnytstva ta kontroliu yakosti veterynarnykh preparativ [Electronic resource]. - Available at: http://zdcsms.zp.ua/news/metodychni-rekomendatsii-shchodo-osnovnykh-pravylnalezhnoi-praktyky-vyrobnytstva-ta-kontroliu-iakosti-veterynarnykh-preparativ

3. Kudlai, I. Otsinka molochnoi produktyvnosti i yakosti moloka [Text] / I. Kudlai // Tvarynnytstvo Ukrainy. - 2010. Vol. 1. - P. 5-8.

4. Klimov, N. T. Effektivnyi kompleks meropriyatiy po bor'be s mastitom korov [Text]: mat. mezhdunar. nauch.-prakt. konf. / N. T. Klimov, V. A. Parikov, V. I. Zimnikov // Sovremennye problemy veterinarnogo obespecheniya reproduktivnogo zdorov'ya zhivotnyh. - Voronezh, 2009. - P. 212-215.

5. Roman, L. G. Osobennosti etiopatogeneza, diagnostiki, terapii i profilaktiki mastita korov v suhostoynyy period [Text]: 
avtoref. diss. ... d-ra vet. nauk / L. G. Roman. - Saratov, 2010. - 20 p.

6. Harazdiuk, H. V. Svoiechasna diahnostyka subklinichnykh form mastytiv - zaporuka oderzhannia ekolohichno chystoho moloka [Text] / H. V. Harazdiuk // Veterynarna medytsyna Ukrainy. - 2011. - Vol. 3. - P. 40.

7. Klimov, N. T. Rol' mikrobnogo faktora v vozniknovenii i razvitii mastita u korov [Text] / N. T. Klimov, V. A. Parikov, V. I. Slobodyanik, E. E. Sheveleva, V. I. Zimnikov, A. N. Modin et. al. // Veterinariya. - 2008. - Vol. 12. - P. 33-36.

8. Baymisheva, D. Sh. Vidovoy sostav mikroflory molochnoy zhelezy pri mastitah [Text] / D. Sh. Baymisheva, L. A. Korosteleva, S. V. Kristoyt, S. V. Kotenkin // Zootekhniya. - 2008. - Vol. 11. - P. 26-28.

9. Larionov, G. A. Vliyanie obrabotki vymeni korov na mikrobiologicheskuyu obsemenennost' moloka [Text] / G. A. Larionov, N. I. Milovidova, L. M. Vyazova // Vestnik veterinarii. - 2012. - Vol. 63. - P. 174-176.

10. Rahmatullin, E. K. Biologicheskie aspekty ispol'zovaniya antisepticheskoy emul'sii dlya soskov vymeni pri mashinnom doenii korov [Text] / E. K. Rahmatullin, I. A. Golovin // Zootekhniya. - 2014. - Vol. 10. - P. 18-19.

11. Dzhons, Dzh. M. Menedzhment sukhostiinykh koriv i borotba z mastytom [Text] / Dzh. M. Dzhon // Veterynarna praktyka. - 2011. - Vol. 7. - P. 28-31.

12. Dmitrieva, O. N. Vliyanie sredstv obrabotki vymeni korov Violit i Kliovit na mikrobiologicheskie pokazateli moloka [Text] / G. A. Larionov, O. N. Dmitrieva // Agrarnyi vestnik Urala. - 2014. - Vol. 7 (125). - P. 40-42.

13. Bilchenko, H. Likuvannia i profilaktyka subklinichnykh form mastytu [Text] / H. Bilchenko // Agroexpert. - 2011. Vol. 7. - P. 93-95.

14. Valyushkin, K. D. Rekomendatsii po primeneniyu effektivnyh metodov diagnostiki, lecheniya i profilaktiki mastitov u korov [Text] / K. D. Valyushkin, S. N. Koval'chuk, V. V. Petrov. - Vitebsk: UO VGAVM, 2005. - 38 p.

15. Modin, A. N. Profilaktika mastita u korov v suhostoynyy period [Text] / A. N. Modin, N. T. Klimov, L. I. Efanova // Zootekhniya. - 2010. - Vol. 10. - P. 27-28.

16. Kostyshyn, Ye. Ye. Metody diahnostyky i likuvannia tvaryn, khvorykh na mastyt [Text]: metod. rek. / Ye. Ye. Kostyshyn, V. Yu. Stefanyk, Ya. I. Ivaniak. - Lviv: LDAVM im. S. Z. Gzhytskoho, 2003. - 64 p.

17. Klimov, N. T. Ekologicheski bezopasnye sposoby lecheniya subklinicheskogo mastita u korov [Text] / N. T. Klimov, Ya. S. Klyuchnikova // Rossiyskiy zhurnal. Problemy veterinarnoy sanitarii, gigieny i ekologii. - 2012. - Vol. 1 (7). - P. $23-26$.

18. Danilov, M. S. Bentonitovyi fitogel' dlya profilaktiki dermatitov soskov vymeni i mastita u korov [Text] / M. S. Danilov, A. L. Vorob'ev // Vestnik Novosibirskogo gosudarstvennogo agrarnogo universiteta. - 2004. - Vol. 4 (20). - P. 79-82.

19. Sachuk, R. M. Klinichne doslidzhennia dii ekolohichno bezpechnoho preparatu "Fitosprei" pry shkirnykh zakhvoriuvanniakh domashnikh miasoidnykh tvaryn [Text] / R. M. Sachuk // Naukovyi visnyk Lvivskoho natsionalnoho universytetu veterynarnoi medytsyny ta biotekhnolohii imeni S. Z. Gzhytskoho. - 2015. - Vol. 17, Issue 1 (61). - P. $297-301$.

20. Koba, I. S. Profilaktika mastita u korov posredstvom obrabotki soskov vymeni [Electronic resource] / I. S. Koba, A. N. Gurchenko, V. E. Tarasov, A. S. Peremyshchev // Veterinariya Kubani. - 2011. - Vol. 2. - Available at: http://www.vetkuban. com/num2_20117.html

21. Borysevych, V. B. Likuvannia koriv, khvorykh na mastyt, nanoakvakhelatamy koloidiv metaliv [Text] / V. B. Borysevych, B. V. Borysevych, V. H. Kaplunenko et. al. // Veterynarna medytsyna Ukrainy. - 2009. - Vol. 7. - P. 20-22.

22. Chopra, I. The increasing use of silver-based products as antimicrobial agents: a useful development or a cause for concern? [Text] / I. Chopra // Journal of Antimicrobial Chemotherapy. - 2007. - Vol. 59, Issue 4. - P. 587-590. doi: 10.1093/ $\mathrm{jac} / \mathrm{dkm} 006$

23. Polova, Zh. M. Mikrobiolohichni doslidzhennia preparatu sribla u miakii likarskii formi [Text] / Zh. M. Polova // Zbirnyk naukovykh prats spivrobitnykiv NMAPO imeni P. L. Shupyka. - 2016. - Vol. 26 (1). - P. 241-246.

24. Derzhavna farmakopeia Ukrainy [Text]. - Derzhavne pidpryiemstvo «Naukovo-ekspertnyi farmakopeinyi tsentr». Kharkiv: RIREH, 2009. - 279 p.

25. Cow comfort [Electronic resource]. - DeLaval. - Available at: http://www.delaval.co.uk/-/Dairy-knowledge-andadvice/Cow-comfort/

26. Silver citrate [Electronic resource]. - Cosmetic database. - Available at: https://www.ewg.org/skindeep/ingredient/ 726680/SILVER_CITRATE/

Рекомендовано до публікації д-р фарм. наук Косяченко К. Л. Дата надходження рукопису 10.05.2017

Zhanna Polova, PhD, Associate Professor, Department of Pharmaceutical and Industrial Technology of Medicines, Bohomolets National Medical University, Tarasa Shevchenka blvd., 13, Kyiv, Ukraine, 01601 E-mail: zpolova@ukr.net 